\title{
Osteogenic potency of human bone marrow mesenchymal stem cells from femoral atrophic non-union fracture site
}

\section{Femoral atrofik birleşmemiş kırık yerinden alınan insan kemik iliği mezenkimal kök hücresinin osteogenic potansiyeli}

Ismail Hadisoebroto Dilogo ${ }^{1}$, Erica Kholinne ${ }^{1}$, Phedy Phedy ${ }^{1}$, Yoshi Pratama Djaja ${ }^{1}$, Yuyus Kusnadi², Lakshmi Sandhow ${ }^{2}$

\begin{abstract}
Objective: Mesenchymal stem cells (MSCs) exist in the site of atrophic non-union fracture. The aim of this study was to evaluate the osteogenic potency of MSCs in order to have a better understanding of the unclear pathophysiology of atrophic non-union fracture

Methods: This is an in vitro experimental study. Sample was obtained from the non-union site of a patient with a 6-years-history of atrophic non-union fracture of right femur. The MSCs was isolated from the fracture site and was cultured in the growth medium. Confirmation of the MSCs was performed and then osteogenic differentiation was performed in mono-layered MSC grown in both home-made and commercial osteogenic media. To evaluate the osteogenic differentiation, we performed Alizarin red staining and colorimetric assay for alkaline phosphatase (ALP).
\end{abstract}

Results: From Alizarin red staining, most cells in the osteoblast medium were stained red by the staining. The result of colorimetric assessment of ALP shows that peak concentration was reached after 4 minutes in osteogenic group and control group.

Conclusion: The presence of ALP activity and positive Alizarin red staining in our study showed that MSCs stem cells obtained from site of atrophic non-union is capable to be differentiated into osteogenic cells. J Clin Exp Invest 2014; 5 (2): 159-163

Key words: Osteogenic potency, Mesenchymal stem cell, non-union fracture

\section{INTRODUCTION}

Non-union fracture is one of the most difficult complications in orthopaedic. These cases often require readmission and surgery, which exaggerate the cost greatly, with an estimate of $£ 13844.68$ for a single

\section{ÖZET}

Amaç: Bu çalışmanın amacı atrofik birleşmemiş kırık patofizyolojisini daha iyi anlamak için bu bölgelerdeki mezenkimal kök hücrelerinin $(\mathrm{MKH})$ osteojenik potansiyelini araştırmaktır.

Yöntemler: Çalışmamız in vitro deneysel bir çalışmadır. Altı yıllık sağ femurda atrofik birleşmemiş kıı öyküsü bulunan bir hastanın kırık yerinden örnek alındı. Mezenkimal kök hücreler kırık bölgesinden izole edildi ve besiyerine kültüre ekildi. Mezenkimal kök hücrelerinin doğrulanma ve daha sonra osteojenik farklılaşması, tek tabakalı MKH ve ticari osteojeik ortamda yapıldı. Osteojenik farklılaşmayı değerlendirmek için Alizarin kırmızı boya ve alkalen fosfataz için kolorimetrik test yapıldı.

Bulgular: Alizarin boyası ile osteoblastik ortamdaki hücrelerin çoğu kırmızıya boyandı. Alkalen fosfatazın kolorimetrtik değerlendirilmesi osteojenik ve kontrol grubunda dört dakika sonra pik konsantrasyona ulaştı.

Sonuçlar: Çalışmamızda alkalen fosfataz aktivitesi varıı̆ı ve pozitif Alizarin kırmızı boyanması atrofik birleşmemiş bölgeden alınan MKH'ların osteojenik hücrelere farkIılaşma potansiyeli olduğunu gösterdi.

Anahtar kelimeler: Osteojenik potansiyel, mezenkimal kök hücre, birleşmemiş kırık

${ }^{1}$ Department of Orthopedic and Traumatology, Faculty of Medicine Universitas Indonesia

${ }^{2}$ Stem Cell Institute, Faculty of Medicine Universitas Indonesia

Correspondence: Yoshi Pratama Djaja

Dept. Orthopaedic and Traumatology, Faculty of Medicine Universitas Indonesia Email: yoshipratamadjaja@yahoo.com

Received: 28.01.2014, Accepted: 30.04.2014

Copyright @ JCEI / Journal of Clinical and Experimental Investigations 2014, All rights reserved 
of non-union [4]. Abundant callus can be found in hypertrophic non-union, indicating ubiquitous blood, oxygen, and nutrient supply. It is considered to be a result of insufficient stability and treatment is directed toward stabilization of the fracture. In atrophic non-union, however, the pathophysiology remains unclear.

Dickson et al suggested poor vascularization as a cause of atrophic non-union [5]. Arterial occlusion in the ipsilateral extremity was associated with a higher rate of delayed union or non-union in open fractures of the tibia. However, Brownlow, Reed and Simpson found that in the animal model, the atrophic non-unions were well vascularized [6].

Centeno et al have reported success in treatment of non-union fractures by percutaneous injection of autologous, culture-expanded, bone marrow-derived mesenchymal stem cells (MSCs). It seemed that lack of MSCs was the cause of the atrophic non-union fracture [7].

In our previous study, we found that MSCs exist in the site of atrophic non-union fracture [8]. However, whether they are capable to differentiate into osteoblast was not evaluated. In the present study, we evaluate the osteogenic potency of MSCs from site of atrophic non-union fracture. Understanding the osteogenic potency of MSCs from site of atrophic non-union will help in better understanding of the unclear pathophysiology of atrophic non-union fracture.

\section{METHODS}

This was an in vitro experimental study. The study was conducted in Cipto Mangunkusumo Hospital and Regenerative and Cellular Therapy (ReGeniC) laboratory in Jakarta, Indonesia during the periods of July-December 2012. Sample was obtained from the non-union site of a 23-year-old patient with a 6 -years-history of atrophic non-union fracture of right femur. During open reduction and internal fixation for atrophic non-union fracture, and before recanalization of the fracture, a $10 \mathrm{ml}$ syringe prefilled with $2 \mathrm{ml}$ heparin $1000 \mathrm{IU} / \mathrm{ml}$ was introduced until it reached the medullary canal. The plunger was then pulled to aspirate the marrow. The procedure was repeated until $10 \mathrm{ml}$ of marrow was obtained. The surgery was then continued following the routine procedure.

Equivalent amount of phosphate buffer saline (PBS) was added to marrow aspirate. The solution was centrifuged at $3000 \mathrm{rpm}, 20^{\circ} \mathrm{C}$ for 30 minutes. Pellet was re-suspended into a $75 \mathrm{~cm}^{2}$ TC flasks with growth medium that contained low glucose Dulbecco's modified eagles medium (Gibco, Grand Island, New York) containing 1000 mg/L D-glucose, L-glutamine, $100 \mathrm{mg} / \mathrm{L}$ sodium pyruvate, and $10 \%$ fetal bovine serum. The suspension was incubated at $37^{\circ} \mathrm{C}, 20 \%$ oxygen and $5 \% \mathrm{CO}_{2}$ flow. After 7 days, the culture was washed several times with PBS and the medium was replaced with fresh medium every 3 day until confluence.

Confirmation of mesenchymal stem cells was performed by flowcytometry. MSCs were washed with $\mathrm{PBS} / 2 \%$ FBS and incubated for 30 minutes in $\mathrm{PE}$-conjugated mouse monoclonal anti-human CD73 (BD Biosciences, San Jose, CA), PE-conjugated mouse monoclonal anti-CD105 (Abcam, Cambridge, UK), FITC-conjugated mouse monoclonal anti-CD45 (BD Biosciences, San Jose, CA), FITC-conjugated mouse monoclonal anti-human CD34 (BD Biosciences, San Jose, CA), PE-conjugated mouse monoclonal anti-CD19 (Abcam, Cambridge, UK), or PE-conjugated mouse monoclonal anti-HLA-DR+DP+DQ (Abcam, Cambridge, UK), or FITC-conjugated mouse monoclonal anti-CD14 (Abcam, Cambridge, UK) antibody. The expression of corresponding markers were detected with flow cytometry (FACSCalibur, Franklin Lakes, NJ) and analyzed with CellQuestPro Software.

Once the MSCs culture reach confluence, osteogenic differentiation was performed in monolayered MSC grown in both home-made and commercially available osteogenic media (MesenCult $\AA$ ) and incubated $37^{\circ} \mathrm{C}, 20 \%$ oxygen and $5 \% \mathrm{CO}_{2}$ flow. Home-made medium contained DMEM, 10\% FBS, $1 \%$ antibiotics, $0.1 \mu \mathrm{M}$ dexamethasone, $50 \mu \mathrm{M}$ ascorbate-2-phosphate, $10 \mathrm{mM} \beta$-glycerophosphate.

After 7 day, cells culture was washed several times with PBS and the medium was replaced with fresh medium every 3 day until confluence. Confluence in commercially available medium was reached in 5 weeks while all cells in the home-made medium failed to survive.

To evaluate osteogenic differentiation, we performed Alizarin red staining and colorimetric assay for alkaline phosphatase (ALP). Undifferentiated mesenchymal stem cells were used as negative control. Colorimetric assay was performed using Alkaline Phosphatase Colorimetric Assay Kit (Abcam, Cambridge, UK) containing p-nitrophenyl phosphate (pNPP) as a phosphatase substrate. Amount of 25 micro liter of cell lysate was prepared using three cycles of freeze-thaw in de-ionized distilled water. The cells lysate was added to a well plate 
with assay buffer and pNPP. The samples were shielded from direct light at room temperature for 1 h. Afterward, L Stop Solution ( $3 \mathrm{~N} \mathrm{NaOH}$ ) was added to the wells and the plate was read at $405 \mathrm{~nm}$ in a micro-plate reader.

\section{RESULTS}

After 3 weeks, the MSCs were successfully isolated and expanded as observed by BMSCs attachment with fibroblast-like morphology appearance in a light microscope with $100 x$ magnification. They were adherent to the TC flask and was not washed in the medium replacement. The confluence of cells was $80 \%-90 \%$ with total number of the cells $3.6 \times 106$ and $2.2 \times 106$. (Figure 1) The MSCs characteristic was confirmed with $\geq 95 \%$ expression of CD105 and CD73 as well as its low expression ( $\leq 2 \%)$ of CD14, CD34, CD45, CD19, and HLA-DR.

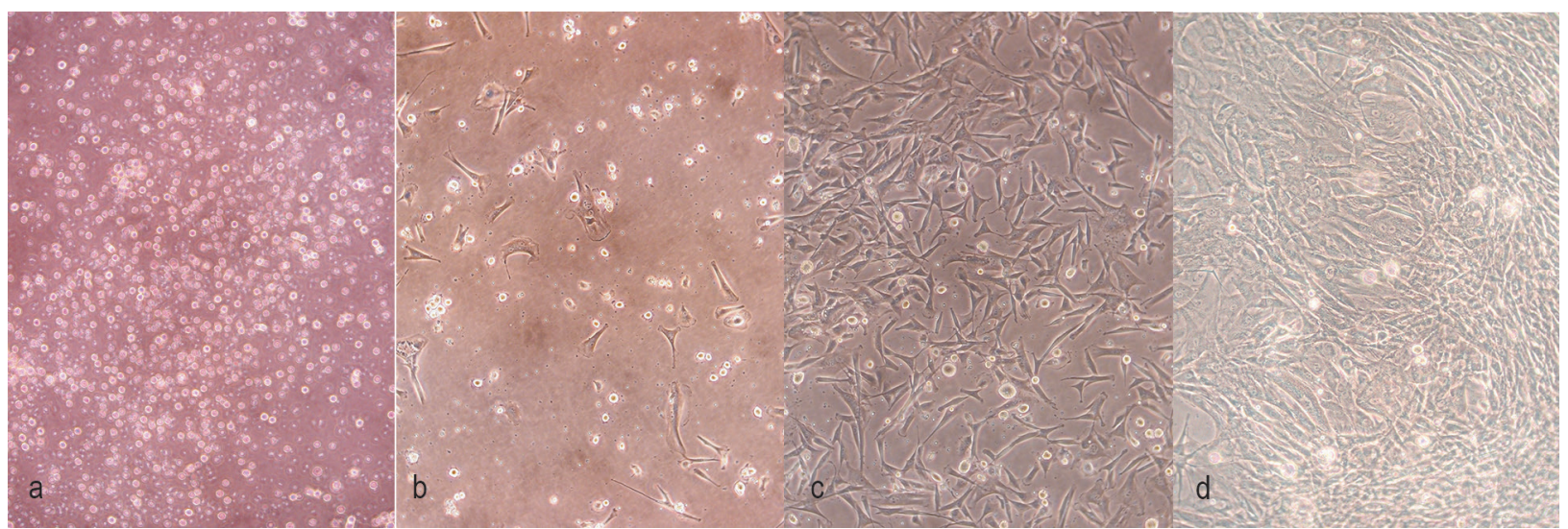

Figure 1. Microscopic evaluation of mesenchymal stem cells (x100).

(a) The first week isolation of BMSCs , the mononuclear cells is adhered to the Tissue Culture Flask undergo periodic medium replacement

(b) On day 5, MSCs were detected with fibroblast-like cells morphology

(c) The end of second week, most of the them are fibroblast like cells adhered to Tissue Culture Flask, minimal mononuclear cells were observed

(d) The end of third week, $90 \%$ of cell confluence, indicating the differentiation process to proceed

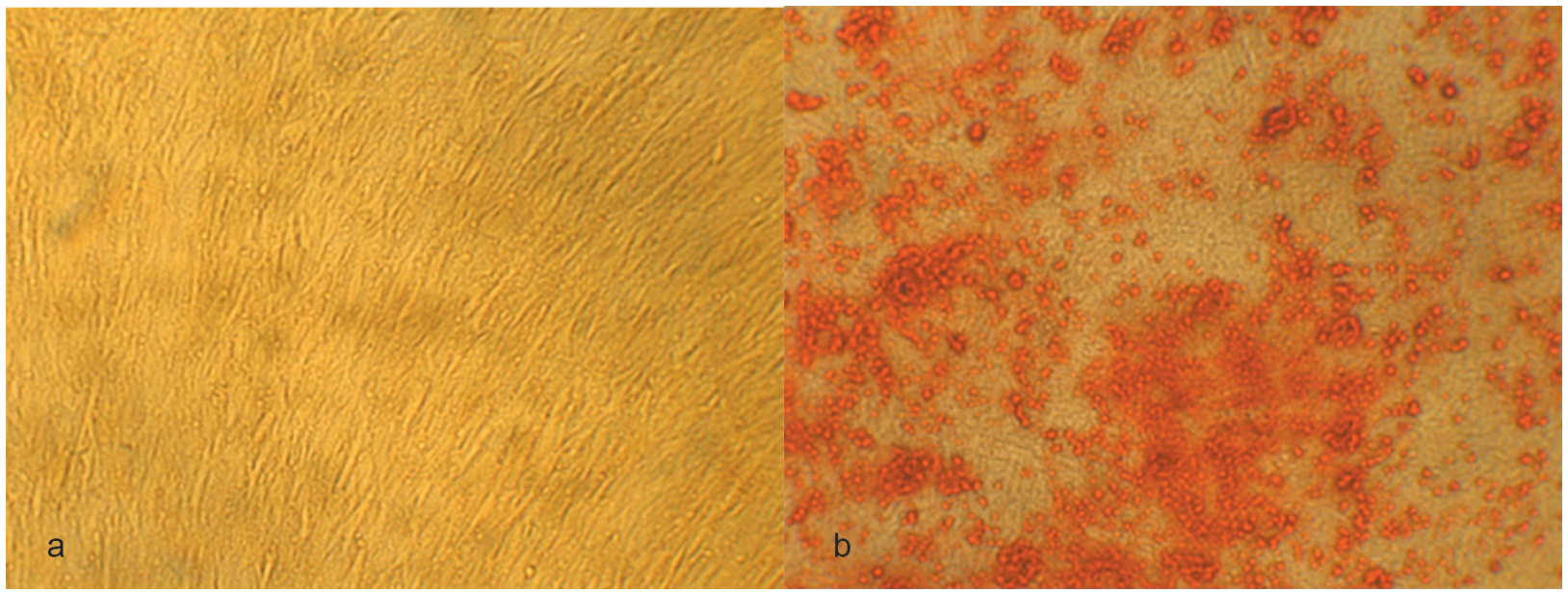

Figure 2. Shows the result of Alizarin red staining of cells in osteogenic medium in comparison to control after 5 weeks of cells culture. Most cells in the osteoblast medium were stained red by the staining

Microscopic evaluation of osteogenic differentiation (alizarin red staining, x100)

(a) control MSCs in growth medium; (b) MSCs in osteogenic medium stained with Alizarin Red 


\section{ALP activities}

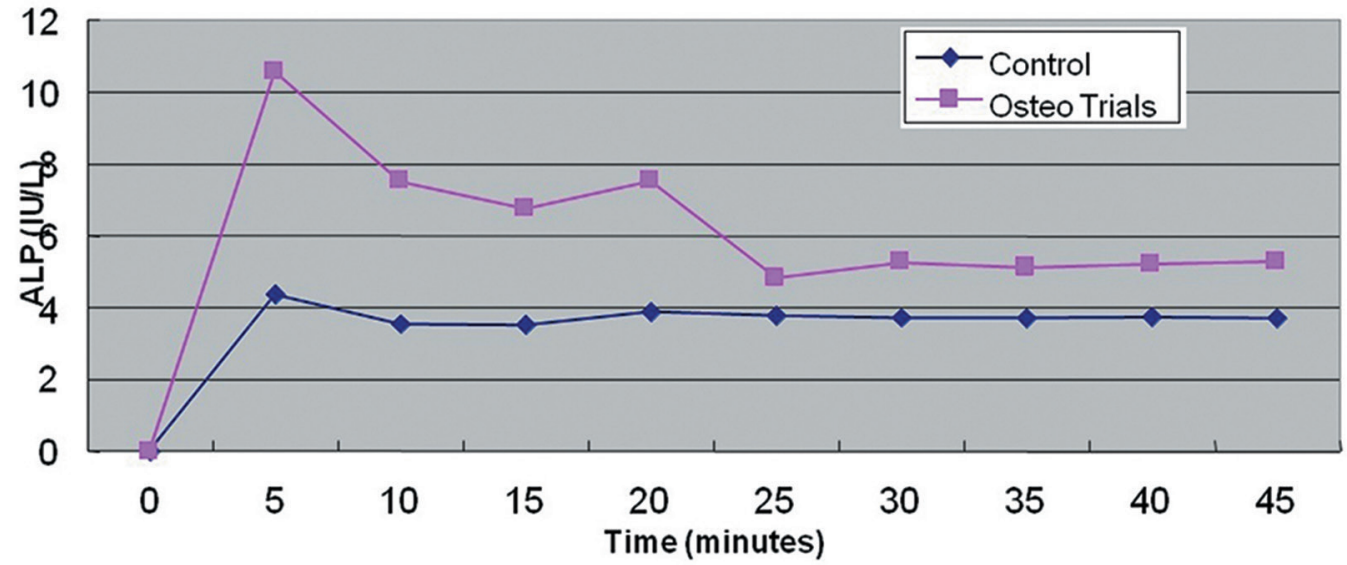

Figure 3. Colorimetric assessment of alkaline phosphatase. Shows the result of colorimetric assessment of ALP. Peak concentration was reach after $4 \mathrm{~min}$ utes in osteogenic group and control respectively.

\section{DISCUSSION}

In our previous study, we revealed the existence of mesenchymal stem cells in atrophic non-union fracture site [8]. However, in our, we did not evaluate the osteogenic potency of those cells in the study. In this study, we evaluated the osteogenic potency of mesenchymal stem cells in the site of atrophic non-union fractures.

Characterization of cells obtained from the site of atrophic non-union fracture confirmed the presence of mesenchymal stem cells. The cells that we obtained were able to adhere to plastic in standard culture condition, positive expression on CD 105, CD 73, CD 90 for at least 95\%, negative expression of CD 45, CD 34, CD 14 or CD 11b, CD 79a, and HLA-DR [9].

Despite similar constituents, we found failure of our home-made medium to induce differentiation of MSCs into osteogenic cells. [10] All cells died before 5 weeks and none was left for further evaluation. The failure might due to the imprecise composition of the medium that influence the milieu. Further researches must be done to evaluate the effect of this homemade osteogenic medium upon its capability in inducing osteogenic differentiation of MSCs. Addition of various chemical substances had been reported to increase the success of osteogenic differentiation [11-13].

Osteogenic differentiation of MSCs can be characterized by various technique, depending on the development stage of the cells; cells proliferation, matrix maturation, and matrix mineralization [14-15].

During cells proliferation, several extracellular matrix proteins can be detected, such as procol- lagen I, TGF-B and fibronectin. Matrix maturation phase is characterized by maximal expression of alkaline phosphatase. During matrix mineralization, proteins such as osteocalsin, bone sialoprotein, and osteopontin are expressed, Calcium deposition during this phase can also be evaluated using adequate staining methods such as Alizarin red.

Marom et al reported ALP was expressed during early stage of differentiation and was involved with matrix mineralization.[16] Alizarin red is a staining method to determine the presence of calcific deposition by cells of an osteogenic lineage during mineralization phase. It is an early stage marker of matrix mineralization [17-18]. The presence of ALP activity and positive Alizarin red staining in our study showed that MSCs stem cells obtained from site of atrophic non-union is capable to be differentiated into osteogenic cells.

Although our study is limited only to one sample, it is a preliminary result for further evaluation of osteogenic potency of mesenchymal stem cells obtained from site of atrophic non-union. Confirmation of this finding will lead to better understanding of pathophysiology of atrophic non-union and improvement in management strategy.

In conclusion, our preliminary study found the possible osteogenic potency of mesenchymal stem cells obtained from non-union site.

\section{REFERENCES}

1. Dahabreh Z, Dimitriou R, Giannoudis PV. Health economics: a cost analysis of treatment of persistent fracture non-unions using bone morphogenetic protein-7. Injury 2007;38:371-377. 
2. Busse JW, Bhandari M, Sprague S, et al. An economic analysis of management strategies for closed and open grade I tibial shaft fractures. Acta Orthop 2005;76:705-712.

3. Garrison KR, Shemilt I, Donell S, et al. Bone morphogenetic protein (BMP) for fracture healing in adults. Cochrane Database Syst Rev 2010;6:CD006950.

4. Megas P. Classification of non-union. Injury 2005;36(Suppl 4):30-37.

5. Dickson K, Katzman S, Delgado E, Contreras D. Delayed unions and non-unions of open tibial fractures: correlation with arteriographic results. Clin Orthop Relat Res 2004;302:189-193.

6. Brownlow HC, Reed A, Simpson AH. Growth factor expression during the development of atrophic nonunion. Injury 2001;32:519-524.

7. Centeno CJ, Schlutz JR, Cheever M, et al. A case series of percutaneous treatment of nonunion fractures with autologous, culture expanded, bone marrow derived mesenchymal stem cells and platelet lysate. J Bioengineer \& Biomedical Sci 2011;S2:007.

8. Ismail HD, Phedy P, Kholinne E, et al. Existence of mesenchymal stem cells in sites of atrophic nonunion. Bone Joint Res 2013;2:118-121.

9. ominici M, Le Blanc K, Mueller I, et al. Minimal criteria for defining multipotent mesenchymal stromal cells. Cytotherapy 2006;4:315-317.

10. Jaiswal N, Haynesworth SE, Caplan Al, et al. Osteogenic Differentiation od Purified, Culture-Expanded Human Mesenchymal Stem Cells In Vitro. J Cell Biochem 1997;64:295-312.

11. Cho HH, Park HT, Kim YJ, et al. Induction of Osteogenic Differentiation of Human Mesenchymal Stem
Cells by Histone Deacetylase Inhibitors. J Cell Biochem 2005;96:533-542.

12. Chen K, Aenlle KK, Curtis KM, et al. Hepatocyte growth factor (HGF) and 1,25-dihydroxyvitamin D together stimulate human bone marrow-derived stem cells toward the osteogenic phenotype by HGF-induced up-regulation of VDR. Bone 2012;51:69-77.

13. Sammons J, Ahmed N, El-Sheemy M, et al. The Role of BMP-6, IL-6, and BMP-4 in Mesenchymal Stem Cell-Dependent Bone Development: Effects on Osteoblastic Differentiation Induced by Parathyroid Hormone and Vitamin D3. Stem Cells Dev 2004;13:273280.

14. Jasiwal RK, Jaiswal N, Bruder SP, et al. Adult human mesenchymal stem cell differentiation to the osteogenic or adipogenic lineage is mitogen-activated protein kinase. J Biol Chem 2000;275:9645-9652.

15. Stein GS and Lian JB. Molecular mechanisms mediating developmental and hormone-regulated expression of genes in osteoblasts:an integrated relationship of cell growth and differentiation. In: Noda M, editor. Cellular and Molecular Biology of Bone. Tokyo: Academic Press. p 47-95,1993.

16. Marom R, Shur I, Solomon R, Benayahy D. Characterization of adhesion and differentiation markers of osteogenic marrow stromal cells. J Cell Physiol 2005;202:41-48

17. Kiernan, JA. Histological and histochemical methods: theory and practice. Butterworth-Heinemann; Boston: 1999. Methods for inorganic ions; p. 267-280.

18. Puchtler H, Meloan SN, Terry MS. On the history and mechanism of alizarin and alizarin red $S$ stains for calcium. J Histochem Cytochem 1969;17:110-124. 